\title{
Komunikasi Pemerintah Kota Medan Dalam Menanggulangi Penyakit Masyarakat
}

\section{(Communication of The Goverment of Medan in Addressing Social Pathology)}

\author{
M. Agha Novrians ${ }^{1 凶}$, Mailin $^{2}$ \\ 1,2 Program Studi Komunikasi dan Penyiaran Islam, Universitas Islam Negeri (UIN) Sumatera Utara, Indonesia \\ email: aghanovrian1130@gmail.com
}

\begin{tabular}{ccc}
\hline First received: & Revised: & Final Accepted: \\
2 May 2020 & 12 May 2020 & 3 June 2020 \\
\hline
\end{tabular}

\begin{abstract}
His research is a field research that examines governmentpolicy issues through communication of the Government of Medan in addressing social pathology in this case prostitution. The research method used in this research is descriptive qualitative method with a phenomenological approach, and uses communication theory. This study aims to analyze the problem of prostitution in the City of Medan, and how to overcome it. The results showed that the disease of prostitution is difficult to eradicate due to several factors; economic factors, education/skill factor (no expertise), religious factors (lack of religious education).
\end{abstract}

Keywords : Communication; Goverment of Medan; Social Pathology.

\section{ABSTRAK}

Penelitian ini merupakan penelitian lapangan meneliti masalah kebijakan pemerintah melalui komunikasi Pemerintah Kota Medan dalam memberantas penyakit masyarakat dalam hal ini prostitusi. Metode penelitian yang digunakan dalam penelitian ini adalah metode kualitatif deskriptif dengan pendekatan fenomenologi, dan menggunakan teori komunikasi. Penelitian ini bertujuan menganalisa masalah penyakit masyarakat prostitusi di Kota Medan, dan bagaimana cara penanggulangannya. Hasil penelitian menunjukkan bahwa penyakit masyarakat prostitusi sulit di berantas kerna beberapa factor yaitu faktor ekonomi, faktor pendidikan/skill (tidak punya keahlian), faktor agama (kurangnya pendidikan agama).

Kata kunci : Komunikasi; Pemerintah Kota Medan; Penyakit Masyarakat.

\section{PENDAHULUAN}

Penyakit masyarakat adalah hal-hal atau perbuatan yang terjadi ditengah-tengah masyarakat yang tidak menyenangkan masyarakat atau meresahkan masyarakat yang tidak sesuai dengan aturan agama dan adat istiadat setempat. Penyakit masyarakat dalam konteks masalah sosial terkait dengan pengangguran, kemiskinan dan lain sebagainya merupakan tanggung jawab negara dalam mengatasinya. Negara sebagai pemangku kewajiban harus bisa memastikan bahwa setiap warga negaranya mempunyai kehidupan yang layak dan lingkungan yang sehat dalam proses interaksi sosial.

Penyakit masyarakat merupakan ancaman bagi keamanan masyarakat, mengakibatkan kerusakan pada diri pelaku dan orang lain serta kerusakan lingkungan sosial. Kecenderungannya penyakit masyarakat akan diikuti pula dengan tindakan kejahatan dan kriminalitas sehingga menimbulkan rasa tidak aman pada masyarakat. Sedangkan dalam Undang-Undang, Negara sudah menjamin warga negaranya mendapatkan hak atas rasa aman. Sebagaimana yang tertuang dalam Undang-Undang Dasar Tahun 1945 Amandemen II telah memasukkan rasa aman ini pada pasal 28A-28I. Begitupun pada pasal 30 Undang-Undang 
HAM yang berbunyi Setiap orang berhak atas rasa aman dan tentram serta perlindungan terhadap ancaman ketakutan untuk berbuat atau tidak berbuat sesuatu, dan Pasal 35 UU HAM: Setiap orang berhak hidup di dalam tatanan masyarakat dan kenegaraan yang damai, aman dan tentram yang menghormati, melindungi dan melaksakan sepenuhnya hak asasi manusia dan kewajiban dasar manusia sebagaimana diatur dalam undang-undang ini.

Aktivitas yang termasuk dalam penyakit masyarakat menurut Undang-Undang Nomor 2 Tahun 2002 tentang Kepolisian Negara dalam penjelasan pasal 15 ayat (1) huruf c berbunyi "mencegah dan menanggulangi tumbuhnya penyakit masyarakat. Yang dimaksud dengan penyakit masyarakat antara lain pengemis dan pergelandangan, pelacuran, perjudian, penyalahgunaan obat dan narkotika, pemabukan, perdagangan manusia, penghisapan/lintah darat, dan pungutan liar.

Secara garis besar penyakit masyarakat yang disebutkan oleh undang-undang di atas, bermuara pada satu kepentingan, yaitu kepentingan material. Tidak dapat di tampik, bahwa manusia mempunyai banyak kebutuhan. Kebutuhan minimal yang setiap harinya harus terpenuhi adalah kebutuhan pangan. Pemenuhan atas kebutuhan ini dilakukan dengan cara bekerja. Akan tetapi pekerjaan atau perbuatan dengan melakukan kegiatan-kegiatan yang terkategori dalam penyakit masyarakat tentu bukan perbuatan terpuji. Tindakan ini selain dianggap hina juga dapat menjatuhkan marwah atau harga diri seseorang. Sehingga nilai dirinya menjadi rendah di mata orang lain. Begitupun menurut konsep Islam penyakit masyarakat adalah perbuatan yang dilarang.

Mengingat begitu banyak dampak buruk yang ditimbulkan oleh penyakit masyarakat, dan sebagai bentuk tanggung jawab dalam rangka memberi rasa aman, sejumlah pemerintah daerah di Indonesia mengeluarkan Peraturan Daerah tentang penyakit masyarakat. Apalagi pemerintah pusat telah memberi wewenang kepada pemerintah daerah untuk mengatur tata kota dalam rangka mewujudkan Kota Bestari. Pemerintah Kota Medan termasuk salah satunya. Pemerintah Kota Medan melalui Peraturan Daerah Kota Medan Nomor 6 Tahun 2003 telah membuat Larangan Gelandangan Dan Pengemis Serta Praktek Susila Di Kota Medan.

Diantara penyakit masyarakat, tuna susila adalah perbuatan yang membawa resiko penyakit paling mematikan dan tingkat penularannya yang paling besar dan luas. Adalah penyakit HIV/AIDS yang disebabkan perilaku seks bebas dimana penularannya paling banyak akibat seringnya berganti pasangan. Pelakunya biasa disebut wanita tuna susila (WTS) atau pekerja seks komersial (PSK) atau sering juga disebut pelacur. Pelacur adalah orang yang menjajakan dirinya untuk suatu tujuan materi atau demi kepuasan nafsu (Khumaerah, 2017).

Permasalahan PSK banyak di jumpai di Kota Medan. Khususnya di jalan-jalan umum. Lokasinya pun dapat diketahui dengan mudah di Kota Medan, bahkan salah satu tempatnya sudah menjadi rahasia umum masyarakat bersama yang ada di kota Medan. Beberapa lokasi prostitusi di kota Medan yang dapat di lihat seperti dikawasan Petisah. Kawasan ini juga terdapat banyak salon, spa dan tempat-tempat karaoke (Ramadani, 2018).

Berdasarkan latar belakang inilah, penulis merasa tertarik untuk mlakukan penelitian dengan judul Komunikasi Pemerintah Kota Medan Dalam Penaggulangan Penyakit Masyarakat. Terdapat beberapa permasalahan dalam penelitian ini, yaitu: Bagaimanakah komunikasi pemerintah Kota Medan dalam upaya pencegahan, pemberantasan, dan penanggulangan penyakit masyarakat?, dan Bagaimanakah kerjasama Pemerintah Kota Medan dengan ulama dalam upaya pencegahan, pemberantasan dan penanggulangan penyakit masyarakat?

Penelitian ini bukan penelitian pertama tentang penyakit masyarakat, beberapa penelitiann telah ada, diantaranya penelitian Yogi Aditya Pranata, Model Komunikasi Dinas Pariwisata Kota Surakarta Dengan Pelaku Usaha Dan MUI Dalam Pengembangan Halal Tourism Di Kota Surakarta. Terdapat empat model komunikasi yang dikembangkan terkait dengan subjek penelitian yang dilakukan. Model tersebut mengacu pada model S-R, Model 
Lasswell, Model Shannon dan Weaver dan Model komunikasi alir banyak tahap. Komunikasi yang dibangun oleh Dinas Pariwisata sebagai subjek penelitian masing-memiliki model komunikasi yang berbeda bentuknya dalam mengirimkan pesan kepada setiap sasaran. Seperti komunikasi Dinas Pariwisata dengan Pelaku Usaha menggunakan model S-R. Indentifikasi atas gangguang komunikasi kepada Pelaku Usaha digambarkan dengan model Shannon dan Weaver. Komunikasi melalui media massa menggunakan model Lasswell. Komunikasi Dinas Pariwisata dengan Pelaku Usaha dan MUI menggunakan model komunikasi alir banyak tahap.

Kedua, Mansur Hidayat, Model Komunikasi Kyai Dengan Santri Di Pesantren. Penelitian ini ingin menyusun, memahami, dan menganalisis model komunikasi kyai dengan santri di Pesantren Raudhatul Qur'an An-Nasimiyyah. Penelitian ini menememukan data bahwa Pertama, kedudukan kyai sebagai (sender) komunikator yang dapat membentuk pola komunikasi dibawahnya, Kedua, Dalam konteks komunikasi, kyai dipengaruhi kuat oleh identitas budaya dan status sosial di masyarakat, dengan ini kedudukan kyai adalah sebagai role-model bagi receiver (pengurus dan santri), Ketiga, Pola komunikasi berlangsung dialogis dan instruksional terbatas dengan pola-pola dan sikap tertentu, Keempat, Organisasi dibawah kyai adalah organisasi yang berfungsi sebagai media maupun kepanjangan tangan dari kyai kepada santrinya, Kelima, Santri sebagai receiver (penerima pesan), dan dalam berkomunikasi ke atas (sender) bersifat terbatas dalam persoalan tertentu. Konstruksi model Komunikasi Kyai dengan Santri di Pesantren Raudhatul Qur'an An-nasimiyyah terbentuk dari intensitas interaksi yang tinggi antara Kyai dengan Santri lewat suatu organisasi maupun secara langsung. Sifat komunikasi dari kyai ke bawah adalah mutlak, sedangkan model komunikasi santri (receiver) kepada kyai (sender) adalah terbatas dalam lingkup persoalan tertentu. Dalam komunikasi model demikian maka diharapkan akan lahir keseganan dari santri kepada kyai. Selajutnya dalam proses transfer of knowledge menjadi lebih mudah. Pola komunikasi seperti ini dipandang cukup ideal dalam pendidikan akhlak (Hidayat, 2016).

Fokus kerangka pikir peneliti dimulai dari model komunikasi Pemko Medan dalam upaya pencegahan, pemberantasan dan penanggulangan PSK. Dari Model komunikasi kontemporer yang dilakukan Pemko Medan yaitu model Aristoteles akan dikolaborasikan melalui metode komunikasi yang tertera dalam Al-Qur'an yakni, metode Bi al-hikmah, Manizatul Hasanah dan Mujadalah atau disebut sebagai metode dakwah. Kombinasi dari model Aristoteles dan metode dakwah akan memberi gambaran model komunikasi islami yang digunakan Pemko Medan dalam upaya untuk pencegahan, pemberantasan dan penanggulangan PSK di Kota Medan.

Operasionalisasinya dari metode di atas diterapkan kedalam bentuk metode komunikasi one way communication dan two-way communication. Pilihan metode penelitiannya adalah dengan pendekatan fenomenologis yang dapat memberi gambaran secara jelas tentang indicator yang akan diteliti.

\section{METODE PENELITIAN}

Penelitian ini menggunakan pendekatan kualitatif studi fenomenologi. Fenomenologi akan berusaha untuk membiarkan fenomena berbicara apa adanya tanpa prasangka dan intervensi baik-buruk, positif-negatif, bermoral-tidak bermoral dan sebagainya dari peneliti. Peneliti akan memahami fenomena melalui pemahaman atas ungakapan-ungkapan atau ekspresi yang diungkapkan subjek.

Teknik pengumpulan data utama dalam studi fenomenologi adalah wawancara mendalam dengan subjek penelitian. Kelengkapan data dapat diperdalam dengan menggunakan teknik lain, seperti observasi partisipan, penelusuran dokumen, dan lain-lain. 


\section{HASIL PENELITIAN DAN PEMBAHASAN}

Berdasarkan data yang diperoleh di lapangan, samapai saat ini prostitusi belum dapat dihentikan oleh pemerintah Kota Medan secara menyeluruh. Hal ini dikarenakan semakin berkembangnya praktek prostitusi membuat para pelaku dan penyedia jasa prostitusi merasa seakan akan di legalkan dengan sendirinya. Praktek prostitusi ini bukan hanya sekadar jual beli jasa seks komersial, namun sudah merambah menjadi perdagangan orang (trafficking).

Hal ini sudah di tangani oleh pemerintah dengan berbagai cara melalui kegiatan penyuluhan, seminar, pelatihan pelatihan kerja dan dengan mengeluarkan peraturan daerah. Penerapan sanksi hukum bagi Pekerja seks komersial (PSK) di kota Medan diatur dalam Perda Kota Medan No 6 Tahun 2003 Tentang Larangan Gelandangan Dan Pengemis Serta Praktek Tuna Susila Di Kota Medan, dimana ruang lingkup Perda tersebut menjelaskan tindakan yang bertentangan dengan norma-norma sosial dan keagamaan dan sangat membahayakan kehidupan generasi muda serta dapat menyebabkan penyebaran virus AIDS / HIV dan virus penyakit lainnya yang semakin meluas. Namun, seiring dengan kemajuan dan perkembangan teknologi informasi dan komunikasi, praktek prostitusi ini semakin mudah berkembang melalui media sosial.

Berdasarkan hasil wawancara di lapangan, terdapat beberapa hal penyebab susahnya memberantas praktek prostitusi di Kota Medan, Pertama, Kebutuhan ekonomi yang semakin meningkat, biaya kehidupan sehari-hari, biaya sekolah dan lain-lain. Kedua, Sulitnya lahan pekerjaan, tidak memiliki skill / keterampilan. Ketiga, Kurangnya pengetahuan agama dalam keluarga.

Pemerintah Kota Medan sendiri telah melakukan kerjasama dengan beberapa pihak, diantaranya: Satpol PP, Ormas Islam, Kepolisian, dalam upaya memberantas prostitusi di Kota Medan, baik dengan melakukan razia serta penutupan lokasi, dan penggerebekan. Namun, sampai saat ini praktek prostitusi tetap ada dan beropersai di Kota Medan.

\section{PENUTUP}

Berdasarkan hasil penelitain yang dilakukan, dapat diambil kesimpulan bahwa penyakit masyarakat (Prostitusi) merupakan masalah besar bagi pemerintah dan masyarakat di Kota Medan. Pemerintah sendiri melalui Peraturan daerah yang dikeluarkan belum mampu menaggulangi penyakit masyarakat tersebut. Faktor utama penyakit masyarakat adalah faktor ekonomi dan pendidikan serta pemahaman agama dalam keluarga.

\section{DAFTAR PUSTAKA}

Abd al-Wahab al-Khalaf. (1992). Imu Ushul al-Fiqh, Kuwait: Dar al-Qalam

Abd. Al-Qadir Audah. (2005). Hukum Pidana Islam, Jakarta: Sinar Grafika.

Abū Husayn Ahmad bin Fāris bin Zakariyah. (1972). Mu'jam Maqāyis al-Lugahat, jilid II.

Akhirul Aminullah, dkk. (2014). Model Komunikasi, Sifat Arogansi dan Etika Komunikasi Pemerintah Menuju Pelayanan Prima, Jurnal Komunikasi, Volume 12, Nomor 2.

Alam A.S. (1984). Pelacuran dan Pemerasan, Studi Sosiologi dan Eksploitasi Manusia Oleh Manusia, Bandung: Alumni.

Ali Mahfudh. (1962). Hidayatul al-Mursyidin, Qairo: Daar Al- Kitab al-Araby.

Ali, Z. (2007). Hukum Pidana Islam, Jakarta: Sinar Grafika

Al-Nawawiy. (1972). Shahih Muslim bi Syarh al-Nawawy, Beirut: Dar al-Fikr

Al-Qur'an dan Terjemahannya, Bandung:Penerbit Sinar Baru Algensindo Offset. 
Alwi, H. (2001). Kamus Besar Bahasa Indonesia, Jakarta: Balai Pustaka

Annisa, D.S. (2016). Presentasi Diri Pekerja Seks Komersial Emporium, Jakarta, Fakultas Ilmu Sosial dan Politik Universitas Sultan AGUNG Tirtayasa

Ardila. (2004). Upaya Penanggulangan Prostitusi, Studi di Polresta Bandar Lampung,Jurnal Politik

Aryani, D. (2015). Perilaku Pencegahan Infeksi Menular Seksual pada Wanita Pekerja Seksual Kabupaten Tegal, Jurnal Kemas

Badi'ah, S. (2018). Problem Solving Patologi Sosial Dalam Perspektif Islam, Jurnal Al-Adyan, Volume 13, No. 2.

Buluamang, Y.M.O. \& Handika, L.P. (2018). Komunikasi Pemerintahan Antar Pemerintah Daerah Di Provinsi Nusa Tenggara Timur (NTT'), Jurnal Penelitian Komunikasi, Vol. 21 No. 1.

Cangara, H. (2011), Pengantar Ilmu Komunikasi, Edisi Revisi, Jakarta: Rajawali Pers,

Departemen Pendidikan dan Kebudayaan. (1990) Kamus Besar Bahasa Indonesia, Jakarta: Balai Pustaka

Djuarsa, S. (1994). Teori Komunikasi, Jakarta: Universitas Terbuka

Drajat, A. (2008). Komunikasi Islam dan Tantangan Modernitas, Medan: Cita Pustaka

Effendy. \& Uchjana, O. (2003). Ilmu, Teori dan Filsafat Komunikasi, Bandung: PT. Citra Aditya Bakti.

Fathul Bahri An-Nabiry. (2008). Meniti Jalan Dakwah: Bekal Perjuangan Para Da’i Jakarta: Amzah Bumi Aksara

Harahap, N. (2011). Analitiyca Islamica, Medan: UINSU

Hariyati. (2014). Upaya-upaya Pencegahan dan Pola Pencarian Pelayanan Infeksi Menular Seksual (IMS) Perempuan Pekerja Seks di Tempat Prostitusi Bandang Raya Kota Samarinda, Dinas Kesehatan Kabupaten Kutai Timur, Kaltim

Hasan, E. (2007) Komunikasi Pemerintahan, Bandung: Refika Aditama

Hasan, M. (1995) Mengenal Waktu Abnormal, Yogyakarta: Penerbit Kanisisus

Hasbiansyah, O. (2008). Pendekatan Fenomenologi: Pengantar Praktik Peneitian dalam Ilmu Sosial dan Komunikasi, Mediator, Vol. 9, No. 1

Henslin, J.M. (2006). Sosiologi dengan Pendekatan Membumi, Jilid I, Jakarta: Erlangga

Hidayat, M. (2016) Model Komunikasi Kyai Dengan Santri Di Pesantren, Jurnal Komunikasi ASPIKOM, Volume 2 Nomor 6, Mesir: Mustāfa al-Bābi al-Halab wa Awlāduh

HS. Hasibuan. (2008). Kurban Sebagai Wujud Pengabdian Tertinggi Manusia; Kajian Historis, Padang: Makalah Khutbah Idul Adha

Huraerah, A \& Purwanto. (2006) Dinamika Kelompok, Bandung, PT.Refika Aditama

Ibn Qayyim al-Jauziyah. (1998). 'Aun al-Ma`bud; Syarh Sunan Abi Daud, juz I2, Beirut DaralFikr.

Jumantoro, T. (2002). Kamus Ilmu Hadits. Jakarta: Bumi Aksara

Kholil, S. (2007). Komunikasi Islam, Bandung: Cita Pustaka.

Khumaerah, N. (2017). Patologi Sosia Pekerja Seks Komersial (PSK) Perspektif Al-Qur'an, Jurnal AlKhitabah, Vol. III No. 1 
Latif, N. (1979). Teori dan Praktek Dakwah Islamiyah, Jakarta: Firma Dara

Liliweri, A. (2011). Komunikasi Serba Ada Serba Makna, Jakarta: Kencana Prenada Media Group.

Lumenta B. (1998) Penyakit, Citra Alam dan Budaya.Tinjauan Fenomena Sosial, Cet. I, Jakarta: Kanisius

Masyari, A. (1993). Butir-Butir Problematika Dakwah Islamiyah, Cetakan 1 Surabaya: Bina Ilmu

Muhammad, A. (2008). Komunikasi Organisasi, Jakarta: Bumu Aksara

Mulyana, D. (2011). Ilmu Komunikasi Suatu Pengantar, Bandung: Remaja Rosda Karya

Munawaroh, S. (2010). Pekerja Seks Komersial (PSK) di Wilayah Prambanan, Kabupaten Klaten, Jawa Tengah, Dimensia

Muri'ah, S. (2000). Metodelogi Dakwah Kontemporer, Yogyakarta, Mitra Pustaka

Peraturan Daerah Kota Bukittinggi Nomor 9 Tahun 2000 Tentang "Penertiban dan Penindakan Penyakit Masyarakat", Bukittinggi: DPRD dan Pemko

Perda Kota Medan No. 6 Tahun 2003 "Tentang Larangan Gelandangan, Pengemis Serta Tuna Susila”, Medan: DPRD dan Pemko

Pranata, Y.A. (2018). Model Komunikasi Dinas Pariwisata Surakarta Dengan Pelaku Usaha Dan MUI Dalam Pengembangan Hala Tourism Di Kota Surakarta, IAIN Surakarta

Purnamawati. (2013). Perilaku Pencegahan Penyakit Menular Seksual di Kalangan Wanita Pekerja Seksual Langsung, Jurnal Kesehatan Masyarakat Nasional

Raay, C.V. (2004). Sebuah Memoir God's Call Girl: Sang Pelacur Tuhan, Kisah Nyata Mengharukan Tentang Perjalanan Hidup Seorang Mantan Biarawati Yang Menjadi Pekerja Seks Komersial, diterjemahkan oleh Hikmi Akmal, Australia: Harper Collins Publishers.

Ramadani. (2018). Penanganan Pekerja Seks Komersial Ditinjau dari Perda Kota Medan No 6 Tabun 2003 Tentang Larangan Gelandangan, Pengemis Serta Praktek Tuna Susila di Kota Medan, Repositori Institusi USU, Universitas Sumatera Utara,

Ramayulis. (1994). Imu Pendidikan Islam, Jakarta: Kalam Mulia

Rasid, A. (2011). Konseptualisasi Etika Dalam Politik Perspektif Komunikasi Islami, Jurnal Dakwah Vol. 5 No. 2.

Rusdiana (2014). Interaksi Sosial Pekerja Seks Komersial Lokalisasi Bandang Raya dengan Masyarakat Keluraban Mugirejo Kota Samarinda, eJournal Ilmu Sosiatri

Silalahi, U. (2004). Komunikasi Pemerintahan: Mengirim Dan Menerima Informasi Tugas Dan Informasi Publik. Jurnal Administrasi Publik, Vol. 3, No. 1

Siregar, A. (1983). Dolly Membelah Pelacuran Surabaya, Kasus Komplek Pelacuran Dolly, Jakarta: Grafitipers

Soejono D. (1977). Pelacuran Ditinjau dari Segi Hukum dan Kenyataan Dalam Masyarakat, Bandung: Karya Nusantara.

Soelaeman, M.M. (2005). Ilmu Sosia Dasar, Bandung: PT. Refika Aditama.

Sugiyono. (2010). Metode Penelitian Kuantitatif, Kualitatif dan R\&D, Bandung: Alfabeta

Suhandang, K. (2004) Public Relation Perusabaan, Bandung: PT. Nusa Cendikia Senjdjaya

Sulistyaningsih. Endang \& Swasono, Y. (1993). The Seks Industry, Prostituation and Development in Indonesia, Laporan Penelitian Untuk Mahasiswa Mahido, Bangkok 
Undang-Undang Republik Indonesia Nomor 2 Tahun 2002

Walgito, B. Pengantar Psikologi Umum, Yogyakarta: Andi

Wirawa, S. (1993) Sarwono, Sosiologi Kesehatan: Beberapa Konsep Beserta Aplikasinya, Bandung: Gajah Mada University Pres, Cet I

Zakri, A.B. (1982). Da'watul Ilal Islam, Bairūt: Maktabat Dār al-'Arabiyah 